\title{
Pengaruh Gender Terhadap Pengambilan Keputusan di Lingkungan Kerja
}

\author{
Dani Finata Pratama $^{1} *$ dan Harmon Chaniago ${ }^{2}$ \\ ${ }^{1}$ Jurusan Administrasi Niaga, Politeknik Negeri Bandung, Indonesia \\ 2 Jurusan Administrasi Niaga, Politeknik Negeri Bandung, Indonesia
}

\begin{abstract}
:
In a work environment, employees from the staff level to top management once confront a problem that requires decision-making. Gender is a very influential factor in decision making. Gender defined here is not "gender". It is the attitudes or attributes of a man or woman that can change over time and working conditions. This study aims to determine the effect of employee gender differences, knowing the ability of employee decision making and to know how much influence gender to decision making in the working environment of PT Jasa Marga (Persero) Tbk. Purbaleunyi Branch. The research method used is descriptive analysis, classical assumption test, correlation analysis, simple regression analysis, and hypothesis test. The sample in this study were 114 respondents consisting of employees of data processing, staff, up to senior officer. Data collection was done by distributing questionnaires and interviewing employees. Based on the results of data, gender and decision making are in good category. The conclusion of this research is gender influence toward decision making 57,3\%.
\end{abstract}

Keywords: gender, decision making, work environment

\begin{abstract}
Abstrak:
Dalam lingkungan kerja, karyawan dari tingkat staf hingga manajemen puncak pernah berhadapan dengan suatu masalah yang membutuhkan pengambilan keputusan. Gender merupakan faktor yang sangat berpengaruh dalam pengambilan keputusan. Gender yang diartikan disini bukanlah "jenis kelamin". Namun, merupakan sikap atau sifat yang dimiliki seorang pria ataupun wanita yang dapat berubah seiring berjalannya waktu dan kondisi lingkungan kerja. Penelitian ini bertujuan untuk mengetahui dampak perbedaan gender karyawan, mengetahui kemampuan pengambilan keputusan karyawan dan mengetahui berapa besar pengaruh gender terhadap pengambilan keputusan di lingkungan kerja PT Jasa Marga (Persero) Tbk. Cabang Purbaleunyi. Metode penelitian yang digunakan adalah analisis deskriptif, uji asumsi klasik, analisis korelasi, analisis regresi sederhana, dan uji hipotesis. Sampel dalam penelitian ini sebanyak 114 responden yang terdiri dari karyawan data processing, staf, hingga senior officer. Pengumpulan data dilakukan dengan menyebarkan kuesioner dan mewawancarai karyawan. Berdasarkan hasil olah data, gender dan pengambilan keputusan berada pada kategori baik. Kesimpulan dari penelitian ini yaitu adanya pengaruh gender terhadap pengambilan keputusan sebesar 57,3\%.
\end{abstract}

Kata Kunci: gender, pengambilan keputusan, lingkungan kerja

*Email korespondensi:

Dani Finata Pratama

dani.finata.abss13@polban.ac.id

\section{PENDAHULUAN}

Salah satu aset terbesar perusahaan adalah karyawannya, karena karyawan 
secara langsung maupun tidak langsung memberikan kontribusi untuk dapat mencapai visi dan misi perusahaan. Dalam lingkungan kerja, karyawan tingkat staf hingga manajemen puncak tentunya pernah berhadapan dengan suatu masalah yang membutuhkan pengambilan keputusan. Pentingnya pembuatan metode dan SOP (standar operasional prosedur) dalam pengambilan keputusan perlu berdasarkan kebutuhan dan keadaan perusahaan tersebut. Misalnya penyusunan anggaran gaji setiap tahun yang dilakukan perusahaan, atau pemilihan media periklanan. Situasi pengambilan keputusan di lingkungan kerja yang kita hadapi mungkin saja berbeda, hal ini dapat dipengaruhi oleh perbedaan masalah yang akan diatasi oleh orang yang mengambil keputusan (decision maker). Dalam keadaan ketidakpastian, pengambilan keputusan tidak dapat diprediksi apakah dapat memberikan manfaat atau bahkan memberikan kerugian bagi pengambil keputusannya. Ketidakpastian merupakan salah satu situasi keputusan yang paling sering terjadi di lingkungan kerja yang kompleks/perusahaan besar.

Sejalan dengan pengertian gender yang telah dipaparkan pada bagian sebelumnya. Serta kesetaraan gender yang telah semakin terlihat aplikasinya di Indonesia, PT Jasa Marga (Persero) Tbk. faktanya, saat ini dipimpin oleh seorang wanita, yaitu Ibu Desi Arryani yang merupakan wujud nyata dari kesetaraan gender, beliau dapat memimpin perusahaan raksasa dibidang penyedia jalan tol yang notabene dipandang oleh masyarakat luas merupakan pekerjaan bagi seorang pria. Fenomena yang menarik menurut peneliti yaitu adanya perusahaan yang dipimpin oleh seorang wanita diperusahaan BUMN seperti PT Jasa Marga (Persero) Tbk. yang pertama kali di pimpin oleh seorang wanita, fenomena selanjutnya yaitu jumlah karyawan yang didominasi oleh gender pria apakah menentukan sikap atau sifat yang sama dengan gender wanita sebagai jenis kelamin minoritas di lingkungan kerja PT
Jasa Marga (Persero) Tbk. Cabang Purbaleunyi, fenomena selanjutnya yaitu adanya pengambilan keputusan yang tidak sistematis dan tidak menggunakan metode pengambilan keputusan, hal ini dibuktikan pada saat peneliti melakukan praktik kerja lapangan di departemen Community Development Program, terdapat 187 mitra binaan yang tersebar di sekitar ruas tol purbaleunyi pada periode penerimaan bulan januari 2016 sampai dengan juni 2017. Namun, terdapat 128 mitra binaan yang menunggak dalam rentan waktu angsuran bulan januari 2016 hingga juni 2017. Hal ini menunjukan bahwa pengambilan keputusan untuk calon mitra binaan di PT Jasa Marga (Persero) Tbk. cabang Purbaleunyi, kurang baik. Karena lebih dari 50\% mitra binaan menunggak. Fenomena yang terakhir yaitu berasal dari besarnya keinginan peneliti untuk mengamati perusahaan besar dalam mempelajari dan pengimplementasian gender dalam mengkaitkannya terhadap berbagai hal seperti sikap, sifat dan pengambilan keputusan di lingkungan kerja serta hal lainnya yang belum banyak diteliti di Politeknik Negeri Bandung ataupun di Indonesia.

\section{TINJAUAN PUSTAKA}

Menurut Sugihastuti (2007: 23), gender adalah perbedaan perilaku (behavioral differences) antara pria dan wanita yang diaplikasikan secara sosial, yakni perbedaan yang diciptakan oleh manusia melalui proses sosial dan kultural yang panjang. Oleh karena itu gender berubah dari waktu ke waktu, dari tempat ke tempat dan dari lingkungan kerja ke lingkungan kerja lainnya. gender merupakan suatu sifat yang melekat pada seorang pria maupun wanita yang dikonstruksikan secara sosial maupun kultural. Perubahan ciri dan sifat-sifat yang terjadi dari waktu ke waktu dan dari tempat ke tempat lainnya disebut konsep gender. Wanita menurut pandangan masyarakat umum terkenal lemah, cantik, emosional dan keibuan. Adapun pria dikenal kuat, jantan, rasional 
dan perkasa. Perbedaan ciri-ciri dan sifatsifat ini dapat terjadi dari waktu ke waktu, dari satu tempat ke tempat lain. Hal inilah yang dikenal dengan konsep gender. Jadi gender bukanlah kodrat melainkan peran yang ditampilkan oleh budaya yang menempatkan wanita dan pria menjadi feminin dan maskulin (Fakih, 2006: 7). Menurut Mosse (2007: 2), mengartikan gender sebagai seperangkat peran yang, seperti halnya kostum dan topeng di teater, menyampaikan kepada orang lain bahwa kita adalah feminin atau maskulin. Perangkat perilaku khusus ini (yang mencakup penampilan, pakaian, sikap, kepribadian, bekerja di dalam dan di luar rumah tangga, seksualitas, tanggung jawab keluarga dan sebagainya).

Menurut Mulia (2004: 4), gender adalah suatu konsep kultural yang dipakai untuk membedakan peran, perilaku, mentalitas, dan karakteristik emosional antara pria dan wanita yang berkembang dalam masyarakat. Gender adalah sebagai konsep sosial yang membedakan (dalam artian memisahkan) peran pria dan wanita, bersifat dapat dipertukarkan, tidak ditentukan oleh perbedaan biologis atau kodrat melainkan dibedakan atau dipilah menurut kedudukan, fungsi, peranan masing-masing dalam berbagai bidang kehidupan dan pembangunan (Handayani \& Sugiarti, 2008: 5).

Dengan demikian dapat ditarik kesimpulan bahwa gender adalah perbandingan antara pria dan wanita yang dapat didefinisikan sebagai kepribadian, tingkah laku, peran, fungsi, kedudukan, tanggung jawab bahkan kebiasaan dalam menghadapi siatuasi yang dibentuk, dibuat, dan disosialisasikan oleh norma, adat kebiasaan, dan kepercayaan masyarakat dalam lingkungan sosial.

Pengambilan keputusan diyakini merupakan sebuah keadaan yang sangat penting untuk dapat menentukan sebuah pilihan yang diharapkan dapat meningkatkan perkembangan organisasi atau perusahaan, berikut ini adalah pengertian pengambilan keputusan yang dikemukakan oleh Terry (2009), pengambilan keputusan adalah pemilihan alternatif dari dua atau lebih alternatif yang ada untuk menentukan arah tujuan yang hendak dicapai. Sedangkan menurut Silalahi (2002: 207), pengambilan keputusan adalah kegiatan yang dilakukan oleh seorang (pimpinan) atau sekelompok orang (antar pimpinan dan bawahan) dalam usaha memecahkan dan mencari masalah yang dihadapi dengan merumuskan, menetapkan berbagai alternatif. Satu dari berbagai alternatif yang dianggap paling baik, tepat dari rasional dipilih untuk dilaksanakan. Suatu proses yang menyeluruh bukan sekedar tindakan sederhana untuk membuat pilihan antara dua atau lebih alternatif yang ada. Pengambilan keputusan bukan hanya dilakukan oleh para manajer, akan tetapi semua anggota organisasi membuat keputusan yaitu memilih satu di antara sekian banyak alternatif. Minimal ada dua alternatif dan dalam praktiknya lebih dari dua alternatif di mana pengambil/pembuat keputusan (decision maker) harus memilih salah satu berdasarkan pertimbangan atau kriteria tertentu.

(2011: 1), pengambilan $\begin{array}{r}\text { Sumaryanto } \\ \text { keputusan }\end{array}$ merupakan suatu proses pemilihan alternatif terbaik dari beberapa alternatif secara sistematis untuk ditindaklanjuti (digunakan) sebagai suatu cara pemecahan masalah. Mengidentifikasi dan memilih serangkaian tindakan untuk menghadapi masalah tertentu atau mengambil keuntungan dari suatu kesempatan. Pengambilan keputusan menghubungkan juga keadaan organisasi masa kini dengan tindakan yang akan diambil organisasi ke dalam masa depan. pengambilan keputusan menggunakan masa lalu; pengalaman masa lalu positif dan negatif memainkan bagian penting dalam menentukan pilihan mana yang layak atau yang tidak (Stoner et al., 1995: 239)

Dengan demikian kita dapat menarik kesimpulan bahwa pengambilan keputusan adalah sebuah kegiatan individu, kelompok 
atau organisasi untuk dapat mengambil sebuah tindakan alternatif agar mencapai tujuan yang telah ditentukan sebelumnya serta menilai keadaan tertentu untuk dapat memberikan alternatif tindakan yang dilakukan dari proses-proses dengan tujuan memberikan solusi yang terbaik agar dapat digunakan saat ini atau masa yang akan datang. Berdasarkan uraian tersebut, berikut merupakan rumusan kerangka pemikiran dalam penelitian ini:

\section{Gambar 1 Kerangka Pemikiran}

\begin{tabular}{|c|c|}
\hline \multicolumn{1}{|c|}{$\begin{array}{c}\text { Gender } \\
(\mathrm{X})\end{array}$} & \multicolumn{1}{|c|}{$\begin{array}{c}\text { Pengambilan } \\
\text { Keputusan (Y) }\end{array}$} \\
\hline $\begin{array}{c}\text { Dimensi: } \\
\text { 1. Peran }\end{array}$ & $\begin{array}{c}\text { Dimensi: } \\
\text { 2. Mentalitas }\end{array}$ \\
3. Sifat & 2. Situasi \\
4. Perilaku & 3. Rasional \\
5. Understanding & 4. Praktikal \\
& 5. Interpersonal \\
& 6. Kondisi \\
Galea dan Wright & lingkungan \\
(1999); Mulia (2004); & Trumboltz (1979); \\
Handayani dan Sugiarti & Sumaryanto (2011) \\
(2008) & \\
\hline
\end{tabular}

\section{Hubungan Gender dan Pengambilan Keputusan}

Adapun hubungan yang terjadi antara gender dan pengambilan keputusan menurut Handayani \& Sugiarti (2008: 5) bahwa gender adalah sebagai konsep sosial yang membedakan (dalam artian memisahkan) peran pria dan wanita, bersifat dapat dipertukarkan, tidak ditentukan oleh perbedaan biologis atau kodrat melainkan dibedakan atau dipilah menurut kedudukan, fungsi, peranan masing-masing di lingkungan kerja/sosial. Hal ini menyebabkan antara pria dan wanita memiliki sudut pandang dan proses/langkah yang berbeda dalam pengambilan keputusan.

Dalam penelitian yang dilakukan Essers \& Benschop (2007) menemukan bahwa gender berpegnaruh positif dan signifikan terhadap pengambilan keputusan. Bila membandingkan pengambilan keputusan yang terbaik, pengambilan keputusan oleh wanita cenderung emosional dan penuh dengan pertimbangan yang kompleks serta membutuhkan waktu yang cukup lama, sedangkan pengambilan keputusan pria mengedepankan rasionalitas serta logika, cenderung cepat dalam pengambilan keputusan. Kemampuan seseorang untuk dapat mengambil keputusan yang baik dan tepat memerlukan sebuah proses yang panjang, begitu pula yang dihadapi oleh karyawan PT Jasa Marga (Persero) Tbk. Cabang Purbaleunyi, kurangnya kepercayaan diri mengakibatkan mental karyawan rendah, hal ini dibuktikan hasil wawancara dan observasi di lapangan bahwa karyawan terbiasa bekerja dengan berpedoman terhadap SOP yang telah ada, apabila dalam keadaan tanpa adanya pedoman SOP, karyawan cenderung kebingungan dan mencari senior officer yang lebih berpengalaman dalam mengatasi masalah tersebut. Menurut Galea \& Wright (1999) menjelaskan bahwa karyawan yang memiliki kepercayaan diri yang rendah akan kesulitan dalam menghadapi pekerjaan sehari-harinya. Hal ini sejalan dengan yang terjadi oleh karyawan PT Jasa Marga (Persero) Tbk. Cabang Purbaleunyi yang memiliki kepercayaan diri yang rendah, akibatnya sering mengalami kesulitan dalam menyelesaikan pekerjaan yang tidak memiliki SOP atau metode dalam pengambilan keputusan. Rendahnya kepercayaan diri tersebut berhubungan erat dengan pengambilan keputusan yang dilakukan di lingkungan kerja, semakin tingginya kepercayaan dalam menyelesaikan pekerjaan maka semakin tinggi pula kepercayaan diri dalam pengambilan keputusan secara individu, kelompok ataupun organisasi. Kepercayaan diri karyawan dipengaruhi oleh gender karyawan, menurut penelitian yang dilakukan oleh Aterido \& Hallward (2011) menjelaskan bahwa kepercayaan diri pria lebih tinggi dari pada wanita. Hubungan 
yang kuat lainnya yaitu berasal dari faktor karyawan merasa kurang nyaman apabila sedang bekerja diatasi oleh atasan.

Karyawan yang masih terbilang baru dalam bekerja akan merasa risih dan kurang nyaman apabila diatasi oleh atasan. Selain itu, berdasarkan observasi dan hasil olah data ditemukan bahwa mayoritas responden wanita merasa kurang bebas dan merasa terancam apabila diawasi oleh atasan pria dalam berpendapat dan mengambil keputusan. Almeida \& Bremser (2015); Lane, Barry L (2002) sepakat bahwa semakin optimal gender diterapkan di lingkungan kerja maka akan semakin baik dan tepat pula dalam pengambilan keputusan yang dilakukan di lingkungan kerja atau lingkungan sosial. Gender akan menyesuaikan, menyeimbangkan, dan beradaptasi terhadap lingkungan kerja dalam kondisi pengambilan keputusan yang terjadwal ataupun yang tidak terjadwal.

\section{Metode Penelitian}

Penelitian ini terdiri dari dua variabel yaitu gender sebagai variabel bebas (X) dan pengambilan keputusan sebagai variabel terikat (Y). Penelitian ini menganalisis bagaimana metode dan tahap-tahap pengambilan keputusan di lingkungan kerja serta berapa besar pengaruh gender terhadap pengambilan keputusan di lingkungan kerja PT Jasa Marga (Persero) Tbk. Cabang Purbaleunyi. Metode yang digunakan dalam penelitian ini adalah metode penelitian deskriptif analisis. Sedangkan untuk metode analisis data yang digunakan dalam penelitian ini antara lain analisis deskriptif, uji asumsi klasik yang meliput uji normalitas dan linearitas, analisis korelasi, analisis regresi, koefisien determinasi, dan uji hipotesis.

\section{Hasil dan Pembahasan}

Responden dari penelitian ini terdiri dari karyawan senior officer, data processing, staf officer, dan pengumpul tol sebanyak 114 orang.

\section{Identitas Responden}

Adapun gambaran tentang responden yang menjadi sampel dalam penelitian ini diklasifikasikan berdasarkan jenis kelamin, usia, pendidikan terakhir dan masa bekerja.

Tabel 1 menunjukan jumlah responden berdasarkan jenis kelamin yang dibagi menjadi dua kelompok yaitu jenis kelamin pria dan jenis kelamin wanita. Dapat dilihat bahwa dari 114 orang responden, jenis kelamin pria lebih mendominasi dari pada jenis kelamin wanita yaitu sebesar $65 \%$ atau 74 orang. Sedangkan responden wanita sebesar $35 \%$ atau 40 orang.

\section{Tabel 1 Identitas Responden Berdasarkan} Jenis Kelamin

\begin{tabular}{|l|c|c|c|}
\hline & Frequency & Percent & Cum. Percent \\
\hline Pria & 74 & 64.9 & 64.9 \\
\hline Wanita & 40 & 35.1 & 100.0 \\
\hline Total & 114 & 100.0 & \\
\hline
\end{tabular}

Sumber: Olah Data (2017)

Tabel 2 menunjukan jumlah responden berdasarkan usia yang dibagi menjadi empat kelompok yaitu umur antara 20-30 tahun, antara 31-40 tahun, antara 4150 tahun dan $>50$ tahun. Dapat dilihat bahwa dari 114 orang responden, sebesar $57 \%$ atau 65 orang responden berusia 20-30 tahun, $23 \%$ atau 26 orang responden berusia 31-40 tahun, dan $20 \%$ atau 23 orang responden berusia 41-50 tahun.

Tabel 2 Identitas Responden Berdasarkan Usia

\begin{tabular}{|l|c|c|c|}
\hline & Frequency & Percent & Cum. Percent \\
\hline $\begin{array}{l}\text { Antara 20-30 } \\
\text { tahun }\end{array}$ & 65 & 57.0 & 57.0 \\
\hline $\begin{array}{l}\text { Antara 31-40 } \\
\text { tahun }\end{array}$ & 26 & 22.8 & 79.8 \\
\hline $\begin{array}{l}\text { Antara 41-50 } \\
\text { tahun }\end{array}$ & 23 & 20.2 & 100.0 \\
\hline Total & 114 & 100.0 & \\
\hline
\end{tabular}

Sumber: Olah Data (2017)

Tabel 3 menunjukan jumlah responden berdasarkan tingkat pendidikan yang dibagi menjadi empat kelompok yaitu 
SMA/SMK/MA, D3, D4/S1 dan S2. Dapat dilihat bahwa dari 114 orang responden, sebesar $38 \%$ atau 43 orang responden adalah lulusan D4/S1, $33 \%$ atau 37 orang responden adalah lulusan D3, 25\% atau 29 orang responden adalah lulusan SMA/SMK/MA dan $4 \%$ atau 5 orang adalah lulus $\mathrm{S} 2$.

Tabel 3 Identitas Responden Berdasarkan Tingkat Pendidikan

\begin{tabular}{|l|c|c|c|}
\hline & Frequency & Percent & Cum. Percent \\
\hline $\begin{array}{l}\text { SMA/SMK/ } \\
\text { MA }\end{array}$ & 29 & 25.4 & 25.4 \\
\hline D3 & 37 & 32.5 & 57.9 \\
\hline D4/SI & 43 & 37.7 & 95.6 \\
\hline S2 & 5 & 4.4 & 100.0 \\
\hline Total & 114 & 100.0 & \\
\hline
\end{tabular}

Sumber: Olah Data (2017)

\section{Analisis Deskriptif Gender}

Untuk menjawab rumusan masalah yang pertama yaitu Bagaimana gender pada karyawan di lingkungan kerja PT Jasa Marga (Persero) Tbk. Cabang Purbaleunyi menggunakan analisis deskriptif yang dijelaskan sebagai berikut:

Tabel 4 Gender

\begin{tabular}{|l|c|c|c|c|c|}
\hline & $\mathrm{N}$ & Min & Max & Mean & SD \\
\hline Peran & 114 & 3 & 5 & 4.39 & .579 \\
Mentalitas & 114 & 2 & 5 & 3.93 & .649 \\
Sifat & 114 & 3 & 5 & 4.10 & .609 \\
Perilaku & 114 & 3 & 5 & 3.98 & .648 \\
Understanding & 114 & 3 & 5 & 4.13 & .554 \\
Gender & $\mathbf{1 1 4}$ & $\mathbf{3}$ & $\mathbf{5}$ & $\mathbf{4 . 1 0}$ & $\mathbf{. 6 0 7}$ \\
\hline
\end{tabular}

Sumber: Hasil Olah Data SPSS (2017)

Interpretasi variabel gender yang ditunjukkan oleh tabel 4 memperlihatkan bahwa variabel gender memiliki jawaban terendah 3 dan jawaban tertinggi 5 . Dihasilkan nilai rata-rata/mean berada pada interval 3,41-4,20 yang dikategorikan baik, artinya gender yang terjadi di lingkungan kerja PT Jasa Marga (Persero) Tbk. Cabang Purbaleunyi sudah baik. Adapun nilai standard deviation untuk variabel gender sebesar $14,80 \% \quad(0,607 / 4,10 \times 100)$. Nilai tersebut berada di bawah $20 \%$ dari mean yang menunjukkan bahwa variasi jawaban untuk variabel gender kecil, yang berarti sebagian besar responden memiliki persepsi yang sama mengenai variabel gender. Menurut Mulia (2004: 4), menyatakan bahwa gender adalah suatu konsep kultural yang dipakai untuk membedakan peran, perilaku, mentalitas, dan karakteristik emosional antara pria dan wanita yang berkembang dalam masyarakat, hal ini menegaskan bahwa gender bukanlah merujuk kepada jenis kelamin pria dan wanita, namun berkembang kepada hal-hal yang dapat berubah dan dimiliki satu sama lain sebagaimana dimensi yang telah disajikan.

Variabel gender dalam penelitian ini diukur oleh 5 dimensi yaitu peran, mentalitas, sifat, perilaku dan Understanding (pengertian). Berdasarkan hasil perhitungan mean yang ditunjukkan pada tabel 5.5 dapat dilihat bahwa dimensi peran memperoleh nilai mean tertinggi yaitu sebesar 4,39 pada, sedangkan dimensi mentalitas memperoleh nilai mean terendah sebesar 3,93 pada. Dimensi yang memiliki kategori nilai sangat tinggi/sangat baik berdasarkan skala interval 4,21-5,00 yaitu hanya dimensi peran, untuk dimensi lainnya seperti mentalitas, sifat, perilaku dan understanding memiliki kategori nilai tinggi/baik berdasarkan skala interval 3,414,20. Dapat dilihat pada tabel 5.5 statistik deskriptif variabel gender dari setiap dimensi diperoleh angka mean yaitu sebesar 4,10, angka tersebut menandakan bahwa variabel gender telah di aplikasikan dengan baik oleh karyawan di lingkungan kerja PT Jasa Marga (Persero) Tbk. Cabang Purbaleunyi dengan sampel sebanyak 114 orang karyawan terbagi menjadi dua kategori yaitu, jenis kelamin pria sebesar $65 \%$ atau 74 orang. Sedangkan responden wanita sebesar $35 \%$ atau 40 orang. Selain itu dari 114 orang responden, sebesar $57 \%$ atau 65 orang responden berusia 20-30 tahun, hal ini menegaskan bahwa generasi muda menjadi karyawan yang mendominasi di PT Jasa Marga (Persero) Tbk. Cabang Purbaleunyi. Menurut Kasali (2017) 
generasi muda atau biasa disebut generasi millenial memiliki kecepatan dalam beradaptasi dan menerima perubahan yang cepat di lingkungan kerja ataupun lingkungan sosial.

Sejalan dengan pendapat tersebut dibuktikan bahwa aplikasi gender yang notabene masih di padang sebagai jenis kelamin oleh masyarakat umum, tidak demikian oleh karyawan PT Jasa Marga (Persero) Tbk. Cabang Purbaleunyi yang telah menerapkan bahwa gender bukan merujuk kepada jenis kelamin, namun lebih menginepretasikan kepribadian seseorang. Salanjutnya dapat dilihat bahwa dari 114 orang responden, sebesar $38 \%$ atau 43 orang responden adalah lulusan D4/S1, 33\% atau 37 orang responden adalah lulusan D3, dan $4 \%$ atau 5 orang adalah lulus S2, dari data tersebut dapat dikatakan bahwa selain karyawan memiliki rentan usia relatif muda dan didukung oleh pendidikan yang tinggi.

\section{Analisis Deskriptif Pengambilan Keputusan}

Untuk menjawab rumusan masalah yang kedua yaitu Bagaimana pengambilan keputusan di lingkungan kerja karyawan PT Jasa Marga (Persero) Tbk. Cabang Purbaleuny imenggunakan analisis deskriptif yang dijelaskan sebagai berikut:

Tabel 5 Pengambilan Keputusan

\begin{tabular}{|l|c|c|c|c|c|}
\hline & $\mathrm{N}$ & Min & Max & Mean & SD \\
\hline Situasi & 114 & 2 & 5 & 3.75 & .709 \\
Emosional & 114 & 3 & 5 & 4.00 & .620 \\
Rasional & 114 & 3 & 5 & 4.17 & .538 \\
Praktikal & 114 & 2 & 5 & 3.75 & .639 \\
Interpersonal & 114 & 3 & 5 & 3.88 & .608 \\
Kondisi & 114 & 3 & 5 & 3.90 & .581 \\
Lingkungan & $\mathbf{1 1 4}$ & $\mathbf{3}$ & $\mathbf{5}$ & $\mathbf{3 . 9 0}$ & $\mathbf{. 6 1 5}$ \\
Pengambilan & 114 & & & & \\
Keputusan & & & & & \\
\hline
\end{tabular}

Sumber: Hasil Olah Data SPSS (2017)

Interpretasi variabel pengambilan keputusan yang ditunjukkan oleh tabel 5 memperlihatkan bahwa variabel pengambilan keputusan memiliki jawaban terendah 3 dan jawaban tertinggi 5. Nilai rata-rata/mean yang diperoleh adalah 3,90. Dihasilkan nilai rata-rata/mean berada pada interval 3,41-4,20 yang dikategorikan baik, artinya pengambilan keputusan yang terjadi di PT Jasa Marga (Persero) Tbk. Cabang Purbaleunyi sudah baik. Adapun nilai standard deviation untuk variabel pengambilan keputusan sebesar $15,76 \%$ $(0,615 / 3,90 \times 100)$. Nilai tersebut berada di bawah $20 \%$ dari mean yang menunjukkan bahwa variasi jawaban untuk variabel pengambilan keputusan kecil, yang berarti sebagian besar responden memiliki persepsi yang sama mengenai variabel pengambilan keputusan. Menurut Terry (2009), menjelaskan bahwa pengambilan keputusan adalah pemilihan alternatif dari dua atau lebih alternatif yang ada untuk menentukan arah tujuan yang ingin dicapai. Pengambilan keputusan yang dilakukan karyawan akan berdampak kepada perkembangan perusahaan, semakin tepat dalam pengambilan keputusan, maka semakin baik perkembangan perusahaan. Variabel pengambilan keputusan dalam penelitian ini diukur oleh 6 dimensi yaitu situasi, emosional, rasional, praktikal, interpersonal, dan kondisi lingkungan.

Berdasarkan hasil perhitungan mean yang ditunjukkan pada tabel 5.6 dapat dilihat bahwa dimensi rasional memperoleh nilai mean tertinggi yaitu sebesar 4,17, sedangkan dimensi situasi memperoleh nilai mean terendah sebesar 3,75. Seluruh dimensi berada pada kategori nilai yang tinggi/baik berdasarkan skala interval 3,414,20 . Selanjutnya apabila dilihat pada tabel 5.6 statistik deskriptif variabel pengambilan keputusan dari setiap dimensi diperoleh angka mean yaitu sebesar 4,10, angka tersebut menandakan bahwa variabel pengambilan keputusan yang dilakukan oleh karyawan PT Jasa Marga (Persero) Tbk. Cabang Purbaleunyi sudah baik dan tepat. Responden dalam penelitian ini sebanyak 114 orang karyawan terbagi menjadi dua kategori yaitu, jenis kelamin pria sebesar $65 \%$ atau 74 orang. Sedangkan responden wanita sebesar $35 \%$ atau 40 orang. Selain itu menunjukan bahwa dari 114 orang responden, sebesar $57 \%$ atau 65 orang 
responden berusia 20-30 tahun, hal ini menegaskan bahwa generasi muda menjadi karyawan yang mendominasi di PT Jasa Marga (Persero) Tbk. Cabang Purbaleunyi.

$$
\text { Menurut Simon dalam Usman }
$$

(2011), menjelaskan bahwa dalam mengambil keputusan ada empat tahap proses yang harus diperhatikan untuk mendapatkan alternatif keputusan yang baik seperti: kegiatan intelijen: kegiatan seperti halnya di militer, pengambilan keputusan diawali dengan mengintai dan mengindentifikasi situasi dan kondisi lingkungan, kegiatan desain: pengambilan keputusan menemukan, mengembangkan, dan menganalisis kemungkinan dari aksi yang akan diambil, kegiatan pemilihan: pengambilan keputusan memilih satu yang terbaik dari sejumlah alternatif, kegiatan implementasi: menerapkan pengambilan keputusan tersebut dan mengevaluasi hasil yang ada. Salanjutnya dapat dilihat bahwa dari 114 orang responden, sebesar $38 \%$ atau 43 orang responden adalah lulusan D4/S1, $33 \%$ atau 37 orang responden adalah lulusan D3, dan $4 \%$ atau 5

orang adalah lulus S2, dari data tersebut dapat dikatakan bahwa karyawan didukung oleh pendidikan yang tinggi akan memberikan pengalaman untuk dapat membantu mereka menganalisis suatu masalah lebih rinci, agar dapat menemukan alternatif pilihan dalam pengambilan keputusan yang tepat dan efisien.

\section{Analisis Regresi}

Analisis regresi digunakan untuk dapat mengukur besarnya pengaruh variabel bebas terhadap variabel terikat dan memprediksi variabel terikat dengan menggunakan variabel bebas. Analisis regresi yang digunakan dalam penelitian ini adalah analisis regresi linier sederhana (simple linear regression analysis), yaitu analisis regresi linier dengan jumlah variabel pengaruhnya hanya satu. Dalam penelitian ini, gender merupakan variabel independen, sedangkan pengambilan keputusan merupakan variabel dependen. Berikut ini adalah tabel 6 merupakan hasil analisis regresi linier sederhana:

Tabel 6 Analisis Regresi

\begin{tabular}{|l|l|c|c|c|c|c|}
\hline \multicolumn{2}{|c|}{} & \multicolumn{2}{|c|}{$\begin{array}{c}\text { Unstandardized } \\
\text { Coefficients }\end{array}$} & $\begin{array}{c}\text { Standardized } \\
\text { Coefficients }\end{array}$ & \multirow{2}{*}{$\mathrm{t}$} & \multirow{2}{*}{ Sig. } \\
\cline { 2 - 7 } & $\mathrm{B}$ & $\begin{array}{l}\text { Std. } \\
\text { Error }\end{array}$ & Beta & & \\
\hline \multirow{2}{*}{1} & $\begin{array}{l}(\text { Consta } \\
n t)\end{array}$ & 14.167 & $\begin{array}{l}4.63 \\
1\end{array}$ & & 3.059 & .003 \\
\cline { 2 - 6 } & & & & 12.25 & .000 \\
\hline
\end{tabular}

Sumber: Olah Data SPSS (2017)

Dapat kita lihat di tabel 6 analisis regresi digunakan untuk dapat mengetahui persamaan regresi pengaruh gender terhadap pengambilan keputusan. Berdasarkan tabel diatas dapat dilihat konstanta 14.167 (a) dengan koefisiensi regresi linier sebesar 0,757 (b). Dari hasil tersebut diperoleh model regresi sederhana sebagai berikut:

$\mathrm{Y}=\mathrm{a}+\mathrm{bX}$

$Y=14.167+0,757 X$

Dari persamaan regresi sederhana diatas dapat diketahui bahwa nilai konstanta adalah 14.167 dan koefisien regeresi menunjukkan angka 0,757. Dari persamaan tersebut menjelaskan bahwa jika tidak ada perubahan pada gender atau $\mathrm{X}=0$ maka pengambilan keputusan yang dicapai sebesar 14.167 dan jika setiap peningkatan 1 unit gender akan meningkatkan pengambilan keputusan sebesar 0,757 .

\section{Koefisien Determinasi}

Uji ini digunakan untuk menjelaskan pengaruh variabel independen terhadap variabel dependen. Indikator tersebut ditunjukkan dengan angka $\mathrm{R}$ Square. Koefisien determinasi dinyatakan dalam persen $(\%)$ sehingga harus dikalikan dengan $100 \%$. Semakin kuat koefisien korelasi maka semakin besar koefisien determinasi, begitupun sebaliknya. Dalam penelitian ini besarnya koefisien determinasi berfungsi untuk mengetahui besarnya persentase variabel terikat, yaitu pengambilan keputusan, yang dapat diprediksi dengan menggunakan variabel bebas, yaitu gender. 
Tabel 7 Koefisien Determinasi

\begin{tabular}{|l|c|c|c|c|}
\hline Model & $R$ & $\begin{array}{c}R \\
\text { Square }\end{array}$ & $\begin{array}{c}\text { Adjusted } R \\
\text { Square }\end{array}$ & $\begin{array}{c}\text { Std. Error of } \\
\text { the Estimate }\end{array}$ \\
\hline 1 & $.757^{\mathrm{a}}$ & .573 & .569 & 5.108 \\
\hline
\end{tabular}

Sumber: Olah Data (2017)

Dapat kita lihat pada tabel 7 diperoleh angka $\mathrm{R}$ square (angka korelasi yang dikuadratkan atau $0,757^{2}$ ) sebesar 0,573. Angka R square disebut juga sebagai koefisien determinasi, maka besarnya koefisien determinasi adalah 0,573 atau sama dengan 57,3\%. Angka tersebut berarti bahwa sebesar $57,3 \%$ pengambilan keputusan dapat dijelaskan dengan menggunakan variabel gender. Dapat pula dikatakan bahwa gender memberikan kontribusi pengaruh sebesar 57,3\% terhadap pengambilan keputusan. Sedangkan sisanya, yaitu sebesar $42,7 \%$ dipengaruhi oleh kontribusi faktor lain. Besarnya $\mathrm{R}$ square berkisar antara 0 sampai 1 yang berarti semakin kecil angka $\mathrm{R}$ square, maka hubungan kedua variabel semakin lemah. Sebaliknya jika $\mathrm{R}$ square semakin mendekati 1, maka hubungan kedua variabel semakin kuat.

\section{Pengaruh Gender Terhadap Pengambilan Keputusan}

Berdasarkan hasil koefisien determinasi diketahui bahwa nilai R Square adalah 0,573 dan nilai Adjust $\mathrm{R}$ Square adalah 0,569. Maka, dari angka-angka tersebut dapat diartikan bahwa gender memiliki pengaruh sebesar $57,3 \%$ terhadap pengambilan keputusan, dan sisanya sebanyak $42,7 \%$ dipengaruhi oleh variabel lain yang tidak diteliti pada penelitian ini. Berdasarkan hasil observasi dan wawancara di lingkungan kerja PT Jasa Marga (Persero) Tbk. Cabang Purbaleunyi memiliki karyawan yang didominasi oleh pria dan cenderung lebih baik dalam pengambilan keputusan, Hal tersebut didukung oleh hasil penelitian Lane, Barry L (2002) menjelaskan hasil penelitian yang di lakukan di Minnesota State Colleges and Universities System mengungkapkan bahwa wanita lebih komples dan kurang efisien dalam pengambilan keputusan, sedangkan pria cenderung ceroboh namun efisien dalam pengambilan keputusan. Selain itu pembagian tanggung jawab yang diberikan kepada karyawan PT Jasa Marga (Persero) Tbk. Cabang Purbaleunyi bukan berdasarkan perbedaan jenis kelamin, melainkan berdasarkan kemampuan dan keahlian dari setiap karyawan, hal ini sejalan dengan pendapat yang dikemukakan Essers \& Benschop (2007) pria dan wanita memiliki peluang yang sama untuk menjadi karyawan yang profesional. Selain itu khususnya untuk karyawan staf dan data proccessing setiap tiga bulan secara rutin terbiasa untuk mengevaluasi kinerjanya agar lebih maksimal terhadap tugas yang telah diberikan oleh atasan. Pada pembahasan sebelumnya mengenai indikator senang bersosialisasi sangat berhubungan dengan indikator manjaga hubungan sosial, semakin tinggi nilai karyawan dalam bersosialisasi maka akan semakin tinggi nilai indikator menjaga hubungan sosial, hal ini dibuktikan oleh karyawan yang sangat mengedepankan hubungan sosial baik di lingkungan kerja maupun di luar lingkungan kerja. Setiap karyawan tidak memeprsoalkan perbedaan yang melekat pada dirinya, mereka membaur dan menjaga hubungan yang baik dengan setiap karyawan dengan cara melakukan kegiatan bersama serperti makan siang, saling membantu dalam bekerja hingga tidak jarang untuk dapat liburan bersama. Sependapat dengan yang dikemukakan oleh Taylor et al. (2009) bahwa hubungan sosial dipengaruhi oleh stereotip gender antara pria dan wanita yang berinteraksi sosial untuk mencapai hubungan sosial yang ideal.

Berdasarkan tabel 5.7 dapat kita lihat bahwa nilai $\mathrm{t}$ hitung yang didapat dengan signifikansi $\alpha=0,05$ dengan $\mathrm{df}=114-2=$ 112. Dapat dilihat dari tabel tersebut bahwa nilai t hitung sebesar 12.250 sedangkan $t$ tabel sebesar 1,98137. Hal tersebut menunjukkan bahwa $\mathrm{t}$ hitung lebih besar daripada $t$ tabel. Dapat disimpulkan bahwa 
H0 ditolak dan $\mathrm{Ha}$ diterima, atau dapat diartikan bahwa terdapat pengaruh positif dan signifikan antara gender terhadap pengambilan keputusan di lingkungan kerja PT Jasa Marga (Persero) Tbk. Cabang Purbaleunyi. Karena probabilitas jauh lebih kecil dari 0,05 yaitu sebesar 0,000 maka model regresi dapat digunakan untuk memprediksi pengambilan keputusan atau dapat dikatakan bahwa gender berpengaruh terhadap pengambilan keputusan.

Menurut Sumaryanto (2011) situasi adalah keseluruhan faktor-faktor dalam keadaan, yang berkaitan satu sama lain, dan yang secara bersama-sama memancarkan pengaruh terhadap kita beserta apa yang hendak kita perbuat. Situasi ini ada yang bersifat tetap dan ada juga yang berubahubah. Karyawan PT Jasa Marga (Persero) Tbk. Cabang Purbaleunyi dalam praktiknya memahami pentingnya dalam mempelajari situasi dalam pengambilan keputusan, seperti halnya yang terjadi di departemen traffic management menyarankan agar adanya penambahan tempat pemungutan tol agar tidak terjadinya kemacetan yang disebabkan oleh truk-truk besar. Saran ini tentu tidak lantas dijadikan sebuah keputusan, para karyawan di departemen tersebut menganalisis kembali apa dampak yang terjadi dari situasi yang ada kedepannya apabila usulan tersebut diterima. Sejalan dengan pendapat Krumboltz (1979) yaitu kondisi lingkungan (environmental conditions and events) lingkungan berpengaruh pada pengambilan keputusan seperti kesempatan, kebijakan pemerintah, aturan-aturan, peristiwa alam, imbalan material atau penghargaan sosial, sumber alam, kemajuan teknologi, perubahan sosial, keluarga, sistem (pemerintahan, pendidikan), lingkungan masyarakat.

Almeida \& Bremser. (2015) dalam penelitiannya menjelaskan bahwa gender secara signifikan dan positif mempengaruhi pengambilan keputusan manajemen strategis karyawan/agen-agen travel di spanyol. Selain itu gender wanita dikatakan lebih baik dalam memimpin dan mengambil sebuah keputusan karena memikirkan hingga ke hal-hal yang detail dan kompleks. Gender merupakan suatu sifat yang melekat pada kaum pria maupun wanita yang dikonstruksikan secara sosial maupun kultural. Perubahan ciri dan sifat-sifat yang terjadi dari waktu ke waktu dan dari tempat ke tempat lainnya disebut konsep gender (Fakih, 2006: 71). Pengembangan di tempat kerja sebagai sarana untuk mencapai tujuan bisnis. Pada proses pengambilan keputusan dalam bekerja wanita cenderung lebih memilih untuk berdiskusi dengan dua orang atau lebih, sedangkan pria lebih memilih langsung memutuskan tanpa berdiskusi terlebih dahulu (Grisoni \& Beeby, 2007). Eagly \& Carli (2007) dalam bukunya menjelaskan bahwa meskipun beberapa penelitian telah memaparkan bahwa pria dan wanita berperan dalam pekerjaannya yang berorientasi pada tugas, wanita ternyata menunjukkan hubungan yang lebih interpersonal dari pada pria dalam menyelesaikan pekerjaannya secara berkelompok (e.g. Melero, 2011).

Pengambilan keputusan bukan hanya dilakukan oleh para manajer, tetapi semua anggota organisasi membuat keputusan yang mempengaruhi pekerjaan mereka dan organisasi tempat mereka bekerja. Pada intinya pengambilan keputusan dapat disimpulkan sebuah kegiatan seseorang untuk mengambil sebuah tindakan alternatif untuk mencapai tujuan yang telah ditentukan sebelumnya (Robbins \& Coulter, 2007: 80). Sebuah studi terhadap 304 pegawai pemerintahan di Thailand menemukan bahwa perempuan memiliki nilai etika dalam pengambilan keputusan lebih tinggi dari pada laki-laki (Mujtaba et al., 2011).

Fredricks et al. (2014) menyatakan bahwa pembuatan keputusan dipengaruhi oleh gender, kebiasaan, dan persepsi di lingkungan sosial, selain itu pria dan wanita perlu menyadari cara-cara bersosialisasi dapat mempengaruhi perilaku mereka sebagai anggota organisasi, termasuk sebagai bawahan ataupun pemimpin agar 
dapat menghadapi situasi yang tidak terduga. Faktor-faktor ini berada diluar kendali individu, namun memiliki pengaruh signifikan terhadap pengambilan keputusan. Berdasarkan hasil wawancara dan observasi di lapangan menemukan bahwa karyawan lebih memikirkan konsekuensi yang terjadi pada saat pengambilan keputusan ketimbang proses/metode pengambilan keputusan yang dilakukan. Hal tersebut didukung oleh pendapat dari Krumboltz (1979) menjelaskan bahwa belajar (learning experiences) pengalaman belajar mempengaruhi tingkah laku dan putusan. Pengalaman belajar setiap orang berbedabeda. Belajar dibagi menjadi belajar melalui pengalaman langsung, meresponnya dan mendapatkan konsekuensi dari hasil belajarnya. Belajar asosiatif yaitu belajar dengan mengaitkan hubungan antara kejadian-kejadian dan memprediksi konsekuensinya.

Karyawan PT Jasa Marga (Persero) Tbk. Cabang Purbaleunyi cenderung mudah dipengaruhi dalam melakukan pengambilan keputusan, namun sebaliknya sulit untuk mempengaruhi rekan kerja atau para anggota forum dalam pengambilan keputusan, hal ini dilihat dari pengalaman kerja dan pengalaman dalam pengambilan keputusan yang belum banyak dimiliki.

\section{KESIMPULAN DAN SARAN Kesimpulan}

Pandangan gender karyawan di lingkungan kerja PT Jasa Marga (Persero) Tbk. Cabang Purbaleunyi berada pada tingkat yang baik. Hal ini ditinjau dari kelima dimensi untuk gender yaitu peran, mentalitas, sifat, perilaku dan understanding (pengertian).

Pengambilan keputusan di lingkungan kerja PT Jasa Marga (Persero) Tbk. Cabang Purbaleunyi berada pada tingkat yang baik. Hal ini ditinjau dari keenam dimensi untuk variabel pengambilan keputusan yaitu situasi, emosional, rasional, praktikal, interpersonal dan kondisi lingkungan.

Terdapat pengaruh yang positif dan signifikan antara gender dengan pengambilan keputusan. Dengan kata lain, jika pandangan mengenai gender baik/meningkat, maka pengambilan keputusan pun akan baik/meningkat. Berdasarkan nilai koefisien determinasi, pengaruh gender terhadap pengambilan menunjukkan nilai sebesar 0,573. Artinya, gender berkontribusi sebesar 57,3\% terhadap pengambilan keputusan di PT Jasa Marga (Persero) Tbk. Cabang Purbaleunyi, sementara sisanya sebesar $42,7 \%$ dipengaruhi oleh faktor-faktor lain yang tidak diteliti dalam penelitian ini.

\section{Saran}

1. Sebaiknya karyawan meningkatkan kemampuannya dalam meningkatkan mentalitas karena dimensi-dimensi tersebut merupakan dimensi paling rendah pada variabel gender.

2. Sebaiknya karyawan mulai dari manajer, senior officer hingga staf melakukan pembahasan mengenai rancangan dari metode pengambilan keputusan terprogram/terjadwal maupun yang bersifat tidak terprogram/tidak terjadwal, karena bila dilihat dari hasil penelitian yang dilakukan. Karyawan memiliki nilai yang rendah pada dimensi praktikal yang berada di variabel pengambilan keputusan. Ada enam metode pengambilan keputusan yang nantinya dapat dilakukan oleh karyawan PT Jasa Marga (Persero) Tbk. Cabang Purbaleunyi agar lebih optimal dalam pengambilan keputusan, yaitu sebagai berikut: keputusan yang kurang tanggapan: metode ini banyak digunakan dan sekaligus merupakan metode yang biasanya kurang diperhatikan, keputusan dengan otoritas: suatu metode yang efisien jika pimpinan sidang atau rapat mendengarkan secara saksama gagasan anggotanya, keputusan minoritas: keputusan minoritas terjadi jika satu atau dua anggota kelompok dapat mengatasi anggota kelompk lainnya, keputusan mayoritas: metode pengambilan keputusan yang paling banyak dikenal 
orang di Negara yang menerapkan sistem demokrasi, keputusan consensus: metode yang banyak menyita waktu karena memberikan kesempatan kepada semua anggota kelompok untuk berkonsensus. Keputusannya tidak selalu bulat karena memungkinkan ada sebagian kecil anggota kelompok yang tidak setuju, keputusan bulat: metode ini yang paling ideal, tetapi sulit direalisasikan.

\section{DAFTAR PUSTAKA}

Almeida, A. M. M. (2011), "Business and corporate governance in tourism a gender perspective", in Alonso Almeida, M.M. and Rodriguez- Antón, J.M. (Eds), Tourism and Gender, Editorial Sintesis, Madrid, pp. 49-74.

Almeida, A., \& Bremser, K. (2015). "Does gender specific decision making exist?", EuroMed Journal of Business, Vol. 10 Iss: 1, pp.47 - 65 .

Chris, G., \& Wright, B. (1999) "Sex, roles and justice: a study of gender as a predictor of fairness in decision making", Women in Management Review, Vol. 14 Issue: 3, pp.89-98, doi: 10.1108/09649429910269893

Essers, C., \& Benschop, Y. (2007). "Enterprising identities: female entrepreneurs of Moroccan or turkish origin in the netherlands".

Organization Studies, Vol. 28 No. 1, pp. 49- 69.

Fakih, M. (2006)."Analisis Gender dan Transformasi Sosial". Yogyakarta: Penerbit Pustaka Pelajar Offset.

Fredricks, S. M., Tilley, E., \& Pauknerová, D. (2014). "Limited gender differences in ethical decision making between demographics in the USA and New Zealand", Gender in Management: An International Journal, Vol. 29 Issue: 3, pp.126-147, doi: $\quad$ 10.1108/GM08-2012-0069

Handayani, T., \& Sugiarti. (2001). "Konsep dan Teknik Penelitian Gender". Pusat Studi Wanita dan Kemasyarakatan,
Universitas Muhammadiyah Malang.

Handayani, T., \& Sugiarti. (2008). "Konsep dan Teknik Penelitian Gender". Surya Dharma, editor. Malang: UMM Press

Kasali, R. (2017) "Disruption". Jakarta: Penerbit Gramedia Pustaka Utama.

Krumboltz, J.D. (1979) “A Social Learning Theory of Career Decision Making, in A.M". Mitchell.

Moose, J. C. M. (2007). "Gender Dan Pembangunan".Yogyakarta: Penerbit Pustidaka Pelajar.

Mulia, S. M. (2004). "Islam Menggugat Poligami”. Jakarta: Penerbit Gradedia Pustaka Utama. Cetakan. I. Dimensi". Bandung: Penerbit

Silalahi, U. (2010). "Metode Penelitian Sosial". Jakarta: Penerbit Refika Aditama.

Silalahi, U. (2012). "Metode Penelitian Sosial". Bandung: Penerbit Alfabeta.

Simatauw, M., Simanjuntak, L., \& Kuswardono, P. T. (2001). Gender \& Pengelolaan Sumberdaya Alam. Yogyakarta: Yayasan PIKUL.

Terry, G. R. (2009). "Prinsip-Prinsip Manajemen". Jakarta: Penerbit Bumi Aksara

Sugihastuti \& Itsna, H. S. (2007). "Gender dan Inferioritas companies": Wanita", Praktik Kritik Sastra Feminis. Yogyakarta: Pustaka Pelajar.

Williams, J. E., Satterwhite, R. C., \& Best, D. L. (1999). "Pancultural Gender Stereotypes Revisited: The Five Factor Model" Sex Roles, Vol. 40, Nos. 7/8, 1999 